
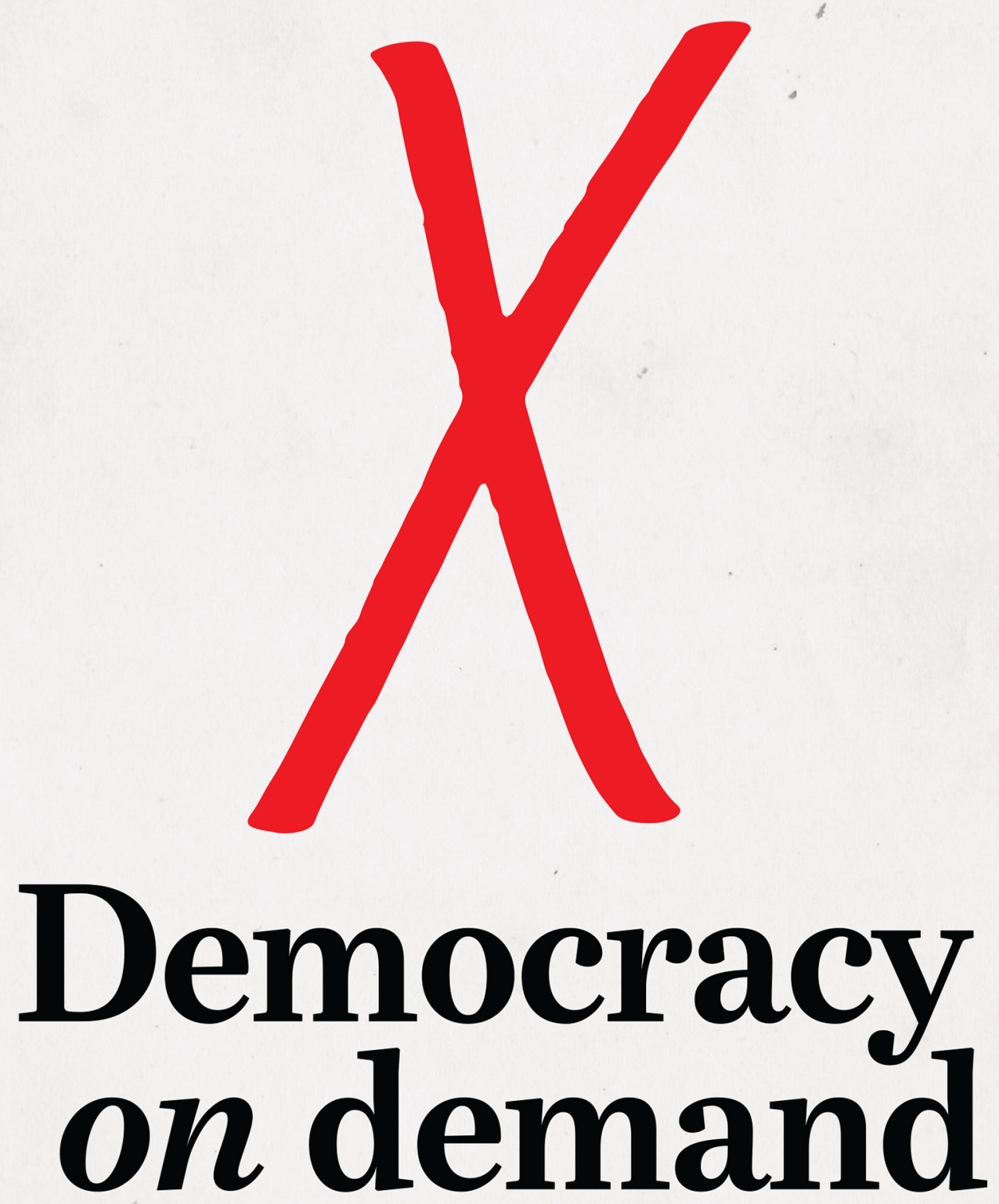

Holding power to account

MATT QVORTRUP 


\section{Democracy on demand}

\section{MANCHESTER 1824}

Manchester University Press 
Matt Qvortrup - 9781526158963

Downloaded from manchesterhive.com at $04 / 26 / 2023$ 02:48:59AM 


\section{Democracy on demand}

Holding power to account

Matt Qvortrup

Manchester University Press 
Copyright (C) Matt Qvortrup 2021

The right of Matt Qvortrup to be identified as the author of this work has been asserted by them in accordance with the Copyright, Designs and Patents Act 1988.

Published by Manchester University Press

Oxford Road, Manchester M13 9PL

www.manchesteruniversitypress.co.uk

British Library Cataloguing-in-Publication Data

A catalogue record for this book is available from the British Library

ISBN 9781526164216 hardback

ISBN 9781526158956 paperback

First published 2021

The publisher has no responsibility for the persistence or accuracy of URLs for any external or third-party internet websites referred to in this book, and does not guarantee that any content on such websites is, or will remain, accurate or appropriate.

Typeset by Newgen Publishing UK 